\title{
Effects of sulfuric, nitric, and mixed acid rain on the decomposition of fine root litter in Southern China
}

\author{
Xin Liu', Miaojing Meng ${ }^{1}$, Yong Zhang ${ }^{2}$, Chong Li ${ }^{1}$, Shilin Ma' ${ }^{1}$ Qinyu Li ${ }^{1}$, Qiong Ren ${ }^{3}$, Yinlong Zhang ${ }^{4}$ and \\ Jinchi Zhang ${ }^{1 *}$
}

\begin{abstract}
Background: China has been increasingly subject to significant acid rain, which has negative impacts on forest ecosystems. Recently, the concentrations of $\mathrm{NO}_{3}{ }^{-}$in acid rain have increased in conjunction with the rapid rise of nitrogen deposition, which makes it difficult to precisely quantify the impacts of acid rain on forest ecosystems.

Methods: For this study, mesocosm experiments employed a random block design, comprised of ten treatments involving 120 discrete plots $(0.6 \mathrm{~m} \times 2.0 \mathrm{~m})$. The decomposition of fine roots and dynamics of nutrient loss were evaluated under the stress of three acid rain analogues (e.g., sulfuric $\left(\mathrm{SO}_{4}{ }^{2-} / \mathrm{NO}_{3}{ }^{-}\right.$5:1), nitric (1:5), and mixed (1:1)). Furthermore, the influences of soil properties (e.g., soil pH, soil total carbon, nitrogen, $\mathrm{C} / \mathrm{N}$ ratio, available phosphorus, available potassium, and enzyme activity) on the decomposition of fine roots were analyzed.

Results: The soil pH and decomposition rate of fine root litter decreased when exposed to simulated acid rain with lower pH levels and higher $\mathrm{NO}_{3}{ }^{-}$concentrations. The activities of soil enzymes were significantly reduced when subjected to acid rain with higher acidity. The activities of soil urease were more sensitive to the effects of the $\mathrm{SO}_{4}{ }^{2-}$ / $\mathrm{NO}_{3}{ }^{-}(\mathrm{S} / \mathrm{N})$ ratio of acid rain than other soil enzyme activities over four decomposition time periods. Furthermore, the acid rain $\mathrm{pH}$ significantly influenced the total carbon (TC) of fine roots during decomposition. However, the S/N ratio of acid rain had significant impacts on the total nitrogen (TN). In addition, the $\mathrm{pH}$ and $\mathrm{S} / \mathrm{N}$ ratio of the acid rain had greater impacts on the metal elements ( $\mathrm{K}, \mathrm{Ca}$, and $\mathrm{Al}$ ) of fine roots than did TC, TN, and total phosphorus. Structural equation modeling results revealed that the acid rain $\mathrm{pH}$ had a stronger indirect impact (0.757) on the decomposition rate of fine roots (via altered soil pH and enzyme activities) than direct effects. However, the indirect effects of the acid rain $\mathrm{S} / \mathrm{N}$ ratio (0.265) on the fine root decomposition rate through changes in soil urease activities and the content of litter elements were lower than the $\mathrm{pH}$ of acid rain.
\end{abstract}

Conclusions: Our results suggested that the acid rain $\mathrm{S} / \mathrm{N}$ ratio exacerbates the inhibitory effects of acid rain $\mathrm{pH}$ on the decomposition of fine root litter.

Keywords: $\mathrm{SO}_{4}{ }^{2-} / \mathrm{NO}_{3}{ }^{-}$of acid rain, Fine root mass loss, Element dynamic, Soil enzyme activity, Soil acidification

\footnotetext{
*Correspondence: zhang8811@njfu.edu.cn

${ }^{1}$ Co-Innovation Center for Sustainable Forestry in Southern China, Jiangsu Province Key Laboratory of Soil and Water Conservation and Ecological Restoration, Nanjing Forestry University, 159 Longpan Road, Nanjing 210037, Jiangsu, China

Full list of author information is available at the end of the article
}

\begin{abstract}
Introduction
Acid rain has emerged as one of the most important global scale environmental challenges ( $\mathrm{Li}$ et al. 2019), and China has become the third most seriously affected regions worldwide to its effects (Liang et al. 2016). Furthermore, the composition of acid rain in China has progressively transitioned from sulfuric acid rain (SAR)
\end{abstract}


to nitric acid rain (NAR) (Liu et al. 2020), due to the recent regulation of sulfur dioxide $\left(\mathrm{SO}_{2}\right)$ emissions, and relatively stable nitrogen oxide $\left(\mathrm{NO}_{\mathrm{x}}\right)$ emissions (Liu and Zhang, 2019; Yu and Duan 2020). Previous studies have found that the ratios of $\mathrm{SO}_{4}{ }^{2-} / \mathrm{NO}_{3}{ }^{-}$in the precipitation of Beijing, Lin'an, and Guangzhou in China decreased from $4.28 \sim 5.40$ to $1.50 \sim 1.81$ over the last few decades (Fang et al. 2011; Li et al. 2010; Wang et al. 2012). Currently, although the overall air quality has been mitigated slightly over the last few years as the result of reduced $\mathrm{SO}_{2}$ and $\mathrm{NO}_{\mathrm{x}}$ emissions, acid rain remains a challenging issue for China (Liu et al. 2019).

Acid rain increases risks to the integrity of forest ecosystem, particularly in terms of its changing compositions (Liu et al. 2018). Plant litter, as one of its main components, plays critical roles in the carbon $(\mathrm{C})$ balance and nutrient cycling of forest ecosystems (Penner and Frank 2019). Previous studies revealed that the $\mathrm{SO}_{4}{ }^{2-} / \mathrm{NO}_{3}{ }^{-}$ratio of acid rain is a significant factor that profoundly influences litter decomposition processes ( $\mathrm{Lv}$ et al. 2014; Liu et al. 2017a). However, these earlier investigations set their primary focus on the decomposition of litters on the ground surface (Wang et al. 2010; Tang et al. 2019) while essentially ignoring the dynamics of fine root decomposition. In contrast to seasonal deciduous leaves, the decomposition of fine roots can occur yearround, which has the function of continuously supplying nutrients to the soil (Xia et al. 2018; See et al. 2019).

The decomposition of fine root litter is mediated by the litter quality (Couteaux et al. 1995; Penner and Frank 2019), soil environment (DeForest 2019; Tresch et al. 2019), and climate (Penner and Frank 2019; Allison et al. 2018). Litter quality is generally considered to be the dominant control of decomposition (Bradford et al. 2016; Chao et al. 2019), where plant litters with higher nitrogen $(\mathrm{N})$ and $\mathrm{N}: \mathrm{C}$ ratios decompose more rapidly (Patoine et al. 2017). Acid rain can alter the soil environment, encompassing soil enzymes and the availability of soil nitrogen (Wang et al. 2010; Liu et al. 2017a). These changes modify the loss dynamics of elements and compounds in fine roots (Wang et al. 2010), which leads to gradual changes in substrate quality, which subsequently impacts the decomposition process (Liu et al. 2017b). However, there are few studies that explore the dynamics of element loss in fine roots under changing acid rain compositions.

Soil enzymes play pivotal roles in litter decomposition and nutrient cycling in forest ecosystems (Lv et al. 2014), where their activities are the direct expression of soil microbial communities to metabolic requirements and available nutrients (Liu et al. 2020; Ling et al. 2010). Previous studies revealed that the inhibitory effects of nitric acid rain (NAR) on most enzyme activities were more obvious than those of sulfuric acid rain (SAR) (Lv et al. 2014; Liu et al. 2020). Nevertheless, there remains a scarcity of data as relates to the impacts of soil enzyme activities on the decomposition of fine root litter under the stress of changing types of acid rain, which seriously affects comprehensiveness and objectivity in the assessment and prediction of global C cycles (Liu et al. 2018; Huang et al. 2019).

To explore the impacts of changing types of acid rain on the decomposition of fine root litter and element loss dynamics, we established a simulated experiment at a Cunninghamia lanceolata (evergreen coniferous) plantation in China, which comprises $\sim 25 \%$ of plantations in the subtropical areas of Southern China (Liu et al. 2018). Based on previous research (Liu et al. 2017a, 2018) we hypothesized that: (1) acid rain inhibits the decomposition of fine root litter and activities of soil enzymes. (2) The negative impacts of simulated acid rain on the decomposition of fine root litter and soil enzyme activities intensify as $\mathrm{NO}_{3}{ }^{-}$concentrations increase.

\section{Methods \\ Study site}

This study was conducted in the Yangtze River Delta Region, which is one of the more seriously affected regions in China in terms of acid rain. The experimental plots were located in a Cunninghamia lanceolata plantation at the Tong Shan Forestry Farm $\left(31^{\circ} 37^{\prime} \mathrm{N}, 118^{\circ} 51^{\prime} \mathrm{E}\right)$ in Nanjing, China. The average annual $\mathrm{pH}$ of the precipitation in China in 2020 was $~ 5.65$, according to the Environment Bulletin of China. Southern China remains a seriously impacted region for acid rain, with the lowest average precipitation $\mathrm{pH}$ value reaching 4.39 (Additional file 1: Fig. S1). The soil type of the C. lanceolata plantation was yellow brown soil and clay with a thickness of $\sim 60 \mathrm{~cm}$. The parent material layer is weathered sandstone, whereas the soil moisture content and temperature were $9.5-27.9 \%$ and $6.1-28.9{ }^{\circ} \mathrm{C}$, respectively. The soil $\mathrm{pH}$, total carbon (TC), total nitrogen (TN), total sulfur (TS), available phosphorus (AP), and available potassium (AK) for the $0-10 \mathrm{~cm}$ soil depth soil were $4.23 \pm 0.12,38.42 \pm 7.91 \mathrm{mg} \mathrm{g}^{-1}, 3.55 \pm 0.63 \mathrm{mg} \mathrm{g}^{-1}$, $0.85 \pm 0.12 \quad \mathrm{mg} \quad \mathrm{g}^{-1}, \quad 2.58 \pm 0.68 \mathrm{mg} \quad \mathrm{kg}^{-1}$, and $35.44 \pm 6.25 \mathrm{mg} \mathrm{kg}^{-1}$, respectively.

\section{Simulated acid rain treatments}

A total of 120 discrete plots $(0.6 \mathrm{~m} \times 2.0 \mathrm{~m})$ were established in the C. lanceolata plantation, which were separated from each other by $\sim 5 \mathrm{~m}$ as described by Liu et al. (2018). Each plot was $1.0 \mathrm{~m}$ from the single C. lanceolata, which was above the plot (Additional file 1: Fig. S2). Ten experimental treatments were formulated, including three categories of acid rain (sulfate acid rain, nitric acid 
rain, and mixed acid rain), three acid rain acidities $(\mathrm{pH}$ 4.5, $\mathrm{pH} 3.5$, and $\mathrm{pH} 2.5$ ), and a control (CK) treatment (local stream water- $\mathrm{pH}$ 6.6). Three replicate plots were randomly selected to receive the simulated acid rain (AR) treatments.

Stock solutions of sulfate acid rain (S), mixed acid rain $(\mathrm{SN})$, and nitric acid rain $(\mathrm{N})$ were prepared by combining $0.5 \mathrm{~mol} \mathrm{~L}^{-1} \mathrm{H}_{2} \mathrm{SO}_{4}$ and $0.5 \mathrm{~mol} \mathrm{~L}^{-1} \mathrm{HNO}_{3}$ at $(\mathrm{S} / \mathrm{N})$ molar ratios of 5:1, 1:1, and 1:5, respectively (Liu et al. 2018). These acid rain solutions were applied to each plot twice monthly using a sprinkler, from March 2015 to February 2016 . The total quantity of applied simulated acid rain was $62.07 \mathrm{~mm}$, the proportions of which were based on the monthly precipitation from 2002 to 2013 (Liu et al. 2017a). The quantities of simulated acid rain during the fine root litter decomposition periods ( 3 months, 6 months, 9 months, and 12 months) were 12.79, 45.15, 54.49 , and $62.07 \mathrm{~mm}$, respectively.

The S3 (S/N 5:1, pH 2.5), SN3 $(1: 1,2.5)$, and N3 $(1: 5,2.5)$ treatments supplied $0.25 \mathrm{~g} \mathrm{~m}^{-2}, 0.92 \mathrm{~g} \mathrm{~m}^{-2}$, $2.29 \mathrm{~g} \mathrm{~m}^{-2}$ nitrogen $(\mathrm{N})$, and $2.85 \mathrm{~g} \mathrm{~m}^{-2}, 2.09 \mathrm{~g} \mathrm{~m}^{-2}$, $1.05 \mathrm{~g} \mathrm{~m}^{-2}$ sulfur (S), respectively, to the plots in contrast to the CK. The $\mathrm{N}$ and $\mathrm{S}$ added to the soil via the $\mathrm{pH} 2.5$ treatments were 10 times that of the $\mathrm{pH} 3.5$ AR treatments, and 100 times that of the $\mathrm{pH} 4.5 \mathrm{AR}$ treatments.

The decomposition of fine root litter was determined using the standard litterbag technique, with the detailed procedure described by Liu et al. (2017a, b). We collected fresh fine roots (first- or second-order roots $\emptyset \leq 2 \mathrm{~mm}$ ) in November 2014 (following the growing season) from the plantation soils under study at a depth of $10 \mathrm{~cm}$, and the fine root litter was manually washed free of soil. Prior to the experiment, all of the fine roots from each species were air-dried and the moisture contents were measured (Liu et al. 2017a). Fine root litterbags $(10 \mathrm{~cm} \times 10 \mathrm{~cm}$, $0.1 \mathrm{~mm}$ mesh polyethylene) were placed in the soil at a depth of $10 \mathrm{~cm}$ (at a $45^{\circ}$ angle relative to the soil surface) in each plot using a hoe with $3 \mathrm{~g}$ air-dried roots (water content 8.41\%) (Liu et al. 2017a) in late February 2015. The initial water, total carbon (TC), total nitrogen (TN), total phosphorus (TP), potassium (TK), calcium (Ca), and aluminum $(\mathrm{Al})$ contents of the fine root litter were determined (Additional file 1: Table S1).

Three fine root litterbags from each of the three simulated acid rain treated plots were collected after 3 months (March to May 2015), 6 months (August 2015), 9 months (November 2015), and 12 months (February 2016) (Additional file 1: Fig. S2). Meanwhile, we collected soil samples at a depth of $10 \mathrm{~cm}$ from around the litterbags. The soil samples were sifted through a $2 \mathrm{~mm}$ sieve to remove leaves, plant roots, gravel, and stones (Liu et al. 2017a). Any soil that adhered to the fine root litter samples was carefully removed, and the litter was manually rinsed with distilled water. The fine root litters were oven-dried at $60{ }^{\circ} \mathrm{C}$ for $24 \mathrm{~h}$ to a constant weight for the determination of mass loss.

\section{Soil and litter properties}

The soil $\mathrm{pH}$ was determined using a $\mathrm{PB}-10 \mathrm{pH}$ meter, and the soil enzyme activities were determined via a spectrophotometer as described by Liu et al. (2017a) and (Liu et al. 2020), respectively. The fine root $C$ and $\mathrm{N}$ were determined using an elemental analyzer (Vario EL III, Elementar, Germany) and described by Liu et al. (2018). The phosphorus (P) concentration was determined using a UV-Vis spectrophotometer, where a $0.25 \mathrm{~g}$ sample was extracted using concentrated nitric acid and perchloric acid (5:1). The digestion solution, which included $\mathrm{K}, \mathrm{Ca}$, and $\mathrm{Al}$ ions, was quantitatively analyzed using an atomic absorption spectrometer (AA900T, Perkin Elmer, MA, USA).

\section{Statistical analyses}

The remaining fine root mass of each sample was expressed as a percentage of the initial fine root dry weight. We applied a first-order exponential decay model $X_{t} / X_{\mathrm{o}}=\mathrm{e}^{-k t}$ to fit the decomposition data (Song et al. 2017), where $X_{t}$ is the net oven-dried weight remaining at time $t ; X_{\mathrm{o}}$ is the initial oven-dried weight; and $k$ is the annual decomposition rate constant $\left(\mathrm{yr}^{-1}\right)$ (Song et al. 2017). The quantity of elements released from the decomposing fine roots were expressed as percentages of the initial element content, which were calculated by the Eq. $E=\left[\left(M_{t} \times C_{t}\right) /\left(M_{\mathrm{o}} \times C_{\mathrm{o}}\right)\right] \times 100$, where $E$ is the quantity of remaining elements (\%); $M_{t}$ is the oven-dried mass at time $t$; and $C_{t}$ is the nutrient concentration at time $t\left(\mathrm{mg} \mathrm{g}^{-1}\right) ; M_{\mathrm{o}}$ is the initial ovendried mass (g); $C_{\mathrm{o}}$ is the initial element concentration $\left(\mathrm{mg} \mathrm{g}^{-1}\right) ; E>100$ indicates element immobilization; and $E<100$ indicates element release (Brandt et al. 2010; Song et al. 2017).

To test whether the soil traits and annual fine root decomposition rates varied under the acid rain treatments, we conducted a series of one-way analyses of variance (ANOVA) with a Duncan test using SPSS 19.0 (SPSS Inc., Chicago, Ill., USA). Three-way ANOVA was employed to assess the effects of the decomposition period, acid rain $\mathrm{pH}$, and $\mathrm{S} / \mathrm{N}$ ratio on the soil traits and litter decomposition using SPSS 19.0. Pearson analysis was performed to reveal the relationships between the fine root decomposition and soil properties under different acid rain treatments in R 3.4.0. Pearson and structural equation modelling analyses were performed using $R$ 3.4.0. and AMOS 24.0, respectively. 


\section{Results}

\section{Soil pH}

The range of $\mathrm{pH}$ values under the CK treatments was $4.04 \pm 0.03 \sim 4.32 \pm 0.04 \quad$ (Fig. 1). Under acid rain stress, the range of soil $\mathrm{pH}$ values shifted to $3.72 \pm 0.03 \sim 4.21 \pm 0.07$. However, no significant differences in the soil $\mathrm{pH}$ were observed between the different acid rain $\mathrm{S} / \mathrm{N}$ ratios $(p>0.05)$. Furthermore, there was a significant difference between the decomposing periods $(p<0.001)$, with the soil $\mathrm{pH}$ values after 6 months being the lowest. The soil $\mathrm{pH}$ values were significantly higher for the $C K$ treatment than under simulated acid rain treatments at $\mathrm{pH} 3.5$ and $2.5(p<0.05)$, except for those at 6 months.

\section{Soil enzyme activities}

The variable trends in soil enzyme activities were similar to those of the soil $\mathrm{pH}$ over the four decomposition periods (Fig. 2), where significant differences were observed between decomposition periods (Additional file 1: Table $S 2, p<0.001)$. In addition, the acid rain $\mathrm{pH}$ significantly influenced the activities of soil enzymes over the four decomposition periods $(p<0.001$ or 0.01 , Additional file 1: Table S2). Acid rain decreased the soil enzyme activities in contrasted to the CK treatments (Fig. 2A, C, D), except for the $\mathrm{pH} 4.5$ acid rain for acid phosphatase activity (Fig. 2B). Furthermore, the $\mathrm{pH} 2.5$ treatments significantly decreased the soil enzyme activities over the four decomposition periods $(p<0.05)$. However, we found that only the $\mathrm{S} / \mathrm{N}$ ratio influenced the activities of urease, acid phosphatase, and catalase over 6 months (Additional file 1: Table S2). The soil urease activity increased significantly with higher acid rain $\mathrm{NO}_{3}{ }^{-}$content $(p<0.05$, Fig. $2 \mathrm{~A})$.

\section{Fine root mass loss and $k$ value of decomposition rate}

The fine root litter masses in the C. lanceolata plantation were rapidly lost during the 1-year experimental period

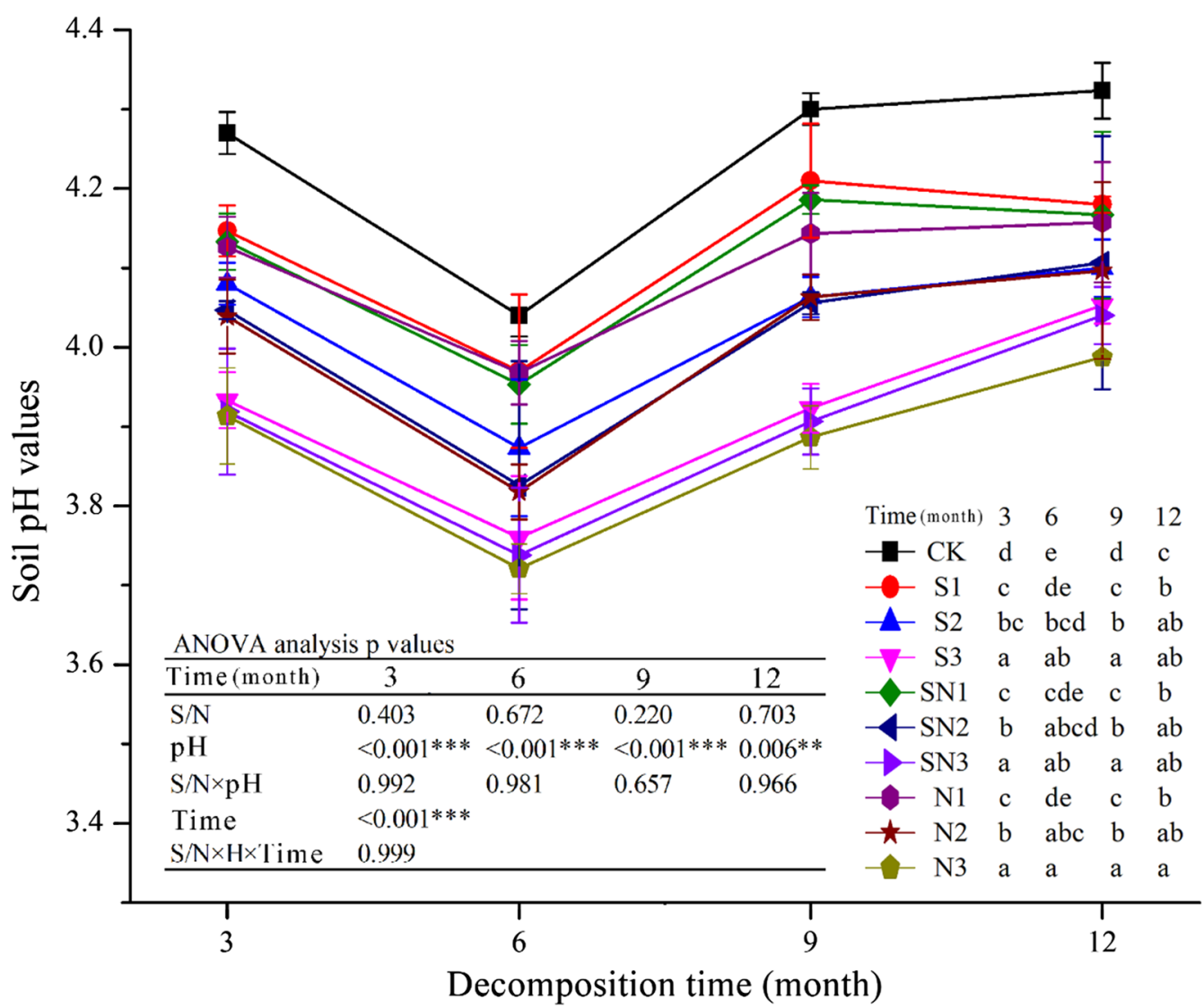

Fig. 1 Change trends of soil $\mathrm{pH}$ values under acid rain stress. The experimental treatments were: $\mathrm{CK}$, control check; S1, pH 4.5, S/N 5:1; S2, pH 3.5, S/N 5:1; S3, pH 2.5, S/N 5:1; SN1, pH 4.5, S/N 1:1; SN2, pH 3.5, S/N 1:1; SN3, pH 2.5, S/N 1:1; N1, pH 4.5, S/N 1:5; N2, pH 3.5, S/N 1:5; N3, pH 2.5, S/N 1:5. Different letters indicate significant difference $(p<0.05)$ between different treatments in the same season based on one-way ANOVA, followed by a Duncan test. Three-way ANOVA was applied to indicate significant differences between variances (no CK treatments). $\mathrm{S}_{\mathrm{N}}$, the ratio of $\mathrm{SO}_{4}{ }^{2-}$ to $\mathrm{NO}_{3}{ }^{-} ; \mathrm{pH}$, acid rain $\mathrm{pH}^{* * *},{ }^{* *}$ and ${ }^{*}$ indicate significant differences at $p<0.001,0.01$, and 0.05 , respectively 


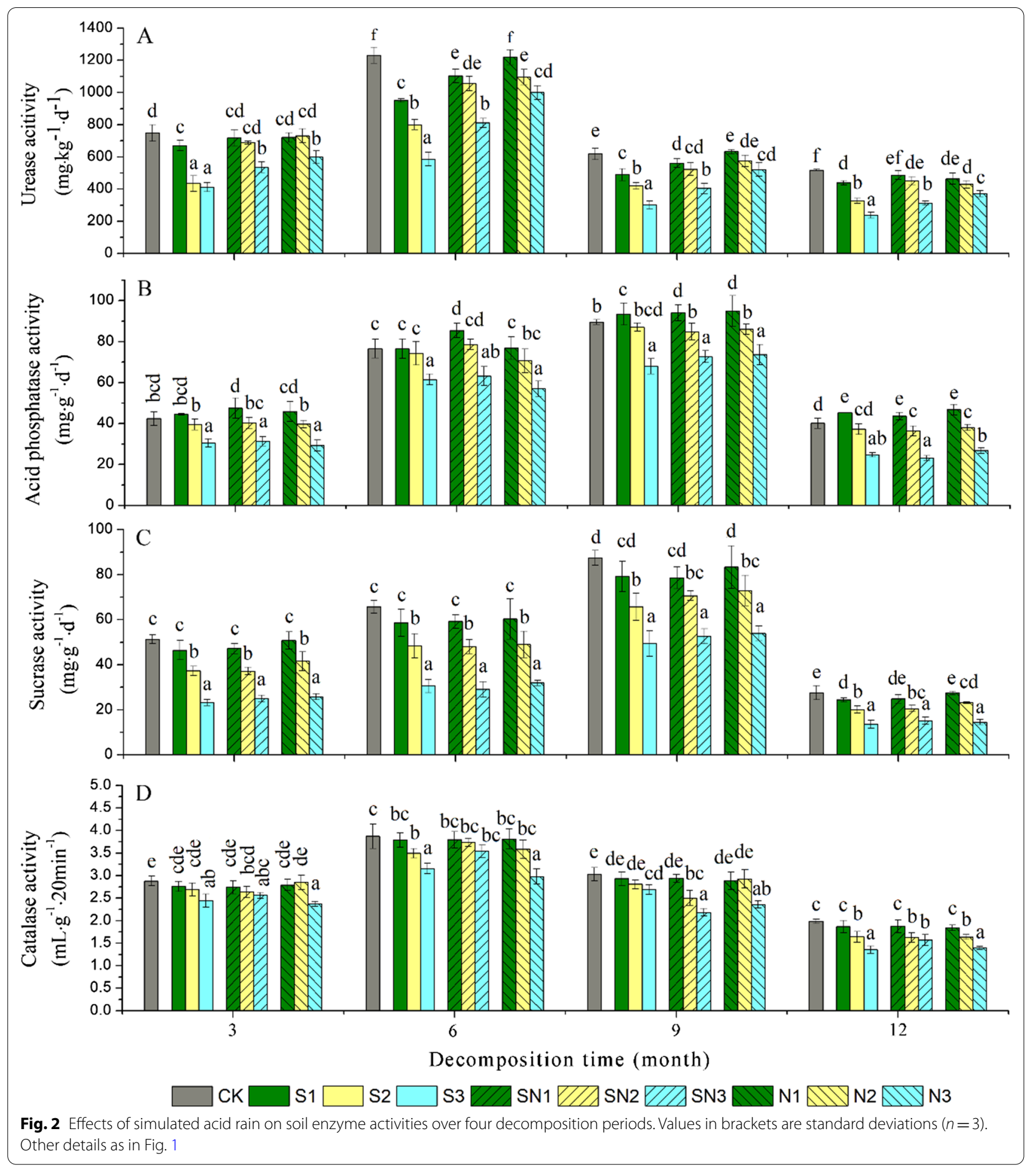

(Fig. 3A-C). The remaining masses under the sulfuric acid rain (S) treatments $(84.04 \pm 2.78 \% \sim 86.22 \pm 1.74 \%)$ during 3 months of decomposition were lower than those under the CK treatments $(86.36 \pm 4.62 \%)$. However, the remaining masses under the mixed sulfuric and nitric acid rain $(\mathrm{SN})$ treatments were greater at lower $\mathrm{pH}$, whereas the nitric acid rain $(\mathrm{N})$ treatments increased the remaining masses during 3 months of decomposition. The minimum fine root litter mass losses under the $\mathrm{S}, \mathrm{SN}$, and $\mathrm{N}$ treatments occurred under the $\mathrm{pH} 2.5$ treatments 

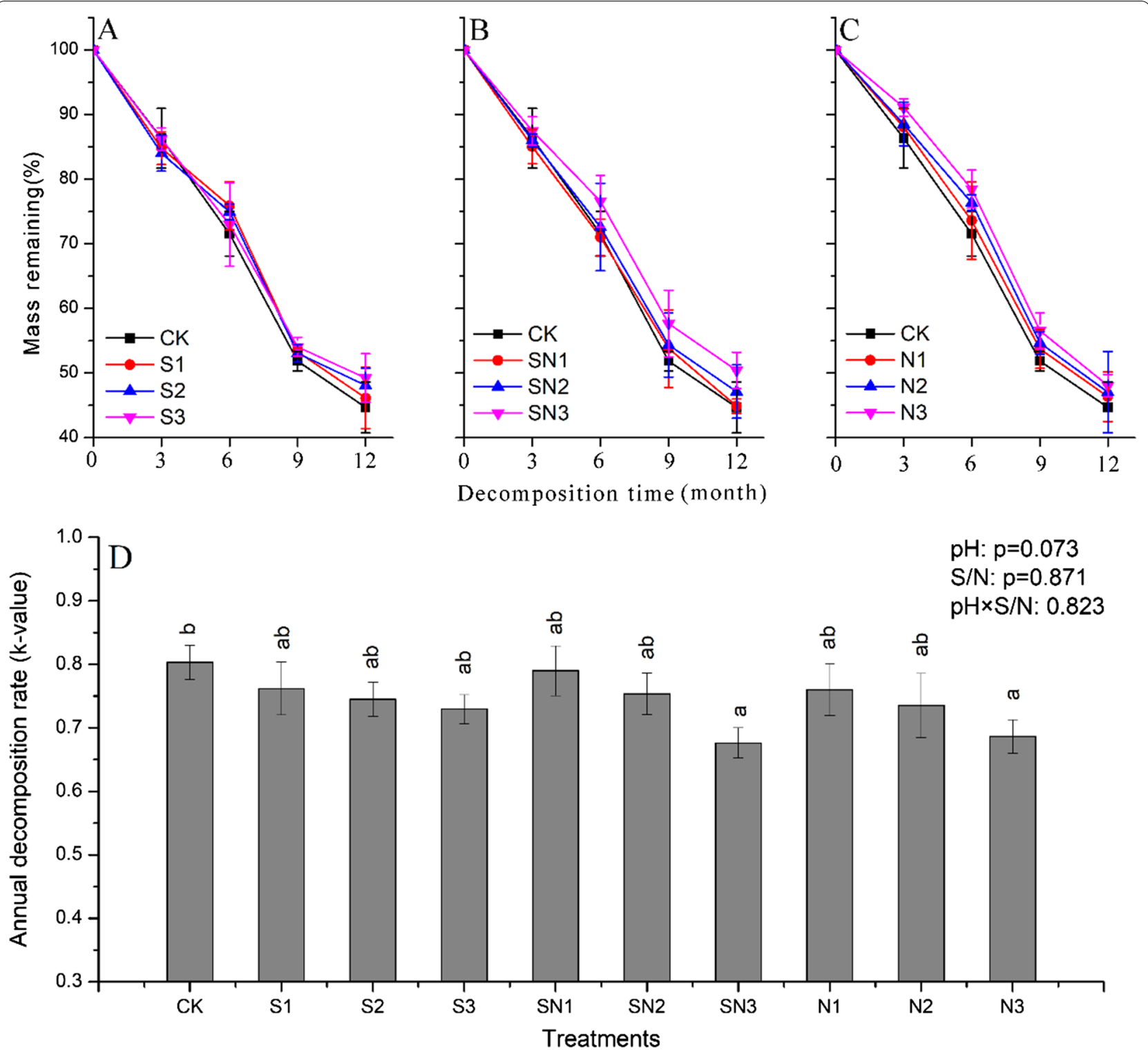

Fig.3 Percentages of mass remaining and annual decomposition rate ( $k$ value) from decomposing fine roots in a $C$. lanceolata plantation under acid rain stress. A Sulfuric acid rain; $\mathbf{B}$ sulfuric and nitric acid rain mixture; $\mathbf{C}$ nitric acid rain; $\mathbf{D} k$ value, calculated using the first-order exponential decay model $\left(X_{t} / X_{o}=e^{-k t}\right)$. Other details as in Fig. 1

after 1 year of decomposition, which were $8.23 \%, 10.37 \%$, and $6.09 \%$ lower than under the CK treatment, respectively. Furthermore, significant inhibitory effects of acid rain $\mathrm{pH}$ on mass loss were observed $(p<0.01$, Additional file 1: Table S3).

The annual fine root litter decomposition rate ( $k$ value) decreased under lower acid rain pH (Fig. 3D). The $k$ values under the SN3 and N3 treatments were significantly lower than those under the CK treatment $(p<0.05)$. However, no significant differences were observed between the acid rain types $(p=0.871)$.
Dynamics of TC, TN, and TP during fine root decomposition The TC, TN, and TP (\% of initial) assessed in this study exhibited significant temporal patterns (Fig. 4, Additional file 1: Table S3). The fine root TC (\% of initial) under all treatments decreased over time (Fig. $4 \mathrm{~A}-\mathrm{C}$ ), where the acid rain $\mathrm{pH}$ significantly inhibited the $\mathrm{C}$ release of the fine root litter $(p=0.004$, Additional file 1: Table S3). The fine root TN (\% of initial) under the CK, S, and SN treatments rapidly decreased over 3 months, and then showed no obvious changes at 6 months (except for SN1 and SN2) (Fig. 4A1, B1). However, the TN under the N1 treatment 

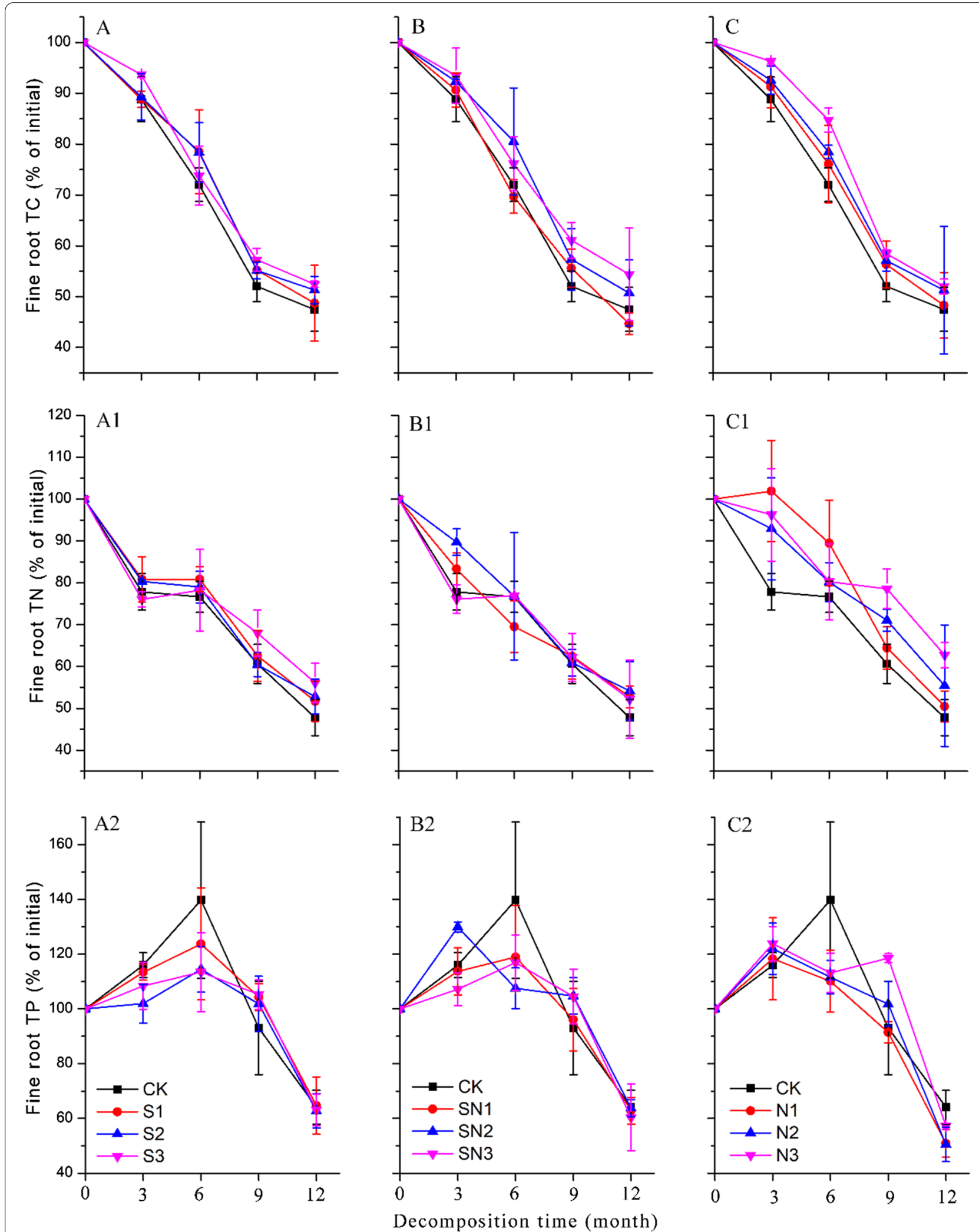

Fig.4 Percentages of TC A, B, and C, TN A1, B1, and $\mathbf{C} 1$ and TP A2, B2, and $\mathbf{C 1}$ remaining in the decomposing fine roots of a C. lanceolata plantation in a 1-year fine root litter decomposition experiment under acid rain stress. A, A1, and $\mathbf{A} 2$ : sulfuric acid rain; B, B1, and B2: sulfuric and nitric acid rain mixture; $\mathbf{C}, \mathbf{C}$, and $\mathbf{C 2}$ nitric acid rain. Other details as in Fig. 1 
initially increased and then decreased (Fig. 4C1). In addition, the acid rain $\mathrm{S} / \mathrm{N}$ ratio significantly influenced the TN over the four decomposing periods $(p<0.001$, Additional file 1: Table S3).

The fine root TP (\% of initial) under the CK, S, SN1, and SN3 treatments initially increased, and then decreased after 6 months (Fig. 4A2, B2). However, the SN2 and $\mathrm{N}$ treatments were shown to decrease the TP over 3 months (Fig. 4B2, C2). After 1 year of decomposition, the remaining percentage and content of TP under the CK treatment were $64.12 \pm 6.19 \%$ and $0.60 \pm 0.03 \mathrm{~g} \mathrm{~kg}^{-1}$, respectively. Moreover, the TP under the $\mathrm{N}$ treatments $(50.48 \pm 6.25 \% \sim 57.19 \pm 1.09 \%)$ was lower than under the S $(62.79 \pm 6.25 \% \sim 64.71 \pm 10.49 \%)$ and SN treatments (60 $.34 \pm 12.17 \% \sim 63.76 \pm 3.16 \%)$. Thus, statistically significant interactions between the influences of acid rain $\mathrm{pH}$ and the $\mathrm{S} / \mathrm{N}$ ratio on the TP were found $(p<0.05$, Additional file 1: Table S3).

\section{Metal dynamics during fine root decomposition}

The fine root litter TK (\% of initial) exhibited a unique pattern in contrast to the TC, TN, and TP in that the TK concentration initially rapidly decreased, which decelerated following 3 months of decomposition (Fig. 5A-C). ANOVA analysis revealed that the acid rain $\mathrm{pH}, \mathrm{S} / \mathrm{N}$ ratio, and decomposition time had significant effects on the release of $\mathrm{K}$ from the fine root litter $(p<0.01$, Additional file 1: Table S3).

The fine root $\mathrm{Ca}$ was immobilized under the CK treatments over 3 months of decomposition. However, acid rain, except for $\mathrm{SN} 1$ and $\mathrm{N} 1$, accelerated the release of $\mathrm{Ca}$ from the fine root litter (Fig. 5A1, B1, C1), particularly under the impacts of stronger acid rain $(\mathrm{pH}=2.5)$. Over 6 months of decomposition, the remaining mass of $\mathrm{Ca}$ under the CK treatment rapidly decreased. Furthermore, we observed that the remaining mass of Ca following 1 year of decomposition increased under the effects of the S1 treatments.

Under the CK, S1, S3, SN3, and N treatments, the fine root $\mathrm{Al}$ was immobilized over 3 months of decomposition, particularly under the N3 treatment (Fig. 5A2, B2, C2). Furthermore, under the $\mathrm{S} 2$ and $\mathrm{N} 3$ treatments, the fine root $\mathrm{Al}$ (\% of initial) increased following 12 months of decomposition (compared to 9 months) and was higher than that under the CK treatment. However, the $\mathrm{S} 1, \mathrm{~S} 3, \mathrm{SN} 1$, and SN2 treatments reduced the fine root $\mathrm{Al}$ in contrast to the CK.

ANOVA analysis indicated that the acid rain $\mathrm{pH}$ and $\mathrm{S} / \mathrm{N}$ ratio had significant effects (both separately and in combination) on the fine root $\mathrm{Ca}$ and $\mathrm{Al}$ of the fine root litter $(p<0.001$ or 0.01 , Additional file 1: Table S3), except for interactive influences on the fine root $\mathrm{Ca}(p=0.274$, Additional file 1: Table S3).

\section{Linking fine root decomposition to soil properties and fine} root elements

There were significant positive correlations between the decomposition rate and soil $\mathrm{pH}$, soil $\mathrm{TN}$, acid phosphatase activity, and sucrase activity (Additional file 1: Figs. S3, S4). However, negative correlations were observed between the decomposition rate and fine root $\mathrm{C} / \mathrm{N}$ ratio, $\mathrm{Al}$, soil $\mathrm{C} / \mathrm{N}$ ratio, and soil available potassium content (AK), albeit they were not significant (Additional file 1: Fig. S4). In addition, the acid rain $\mathrm{pH}$ had significant positive effects on the activities of soil enzymes $(p<0.001)$ and fine root Ca content $(p<0.01$, Additional file 1: Fig. S4). Furthermore, the acid rain $\mathrm{S} / \mathrm{N}$ ratio had significant positive effects on the fine root Ca content $(p<0.05$, Additional file 1: Fig. S4).

The soil and fine root indices were selected according to the correlation analysis between all indices (Additional file 1: Fig. S4) and the model parameter (Fig. 6). The total effect of acid rain $\mathrm{pH}(0.476)$ on the fine root decomposition rate was stronger than that of the acid rain $\mathrm{S} / \mathrm{N}$ ratio $(0.090)$ (Table 1). Furthermore, the direct effects of acid rain $\mathrm{pH}$ on soil properties ( $\mathrm{pHs} 0.948$, phosphatase 0.920), except for soil urease, were stronger than those of the acid rain $\mathrm{S} / \mathrm{N}$ ratio (pHs 0.134, phosphatase -0.041 ) (Fig. 6). However, the direct effects of the acid rain $\mathrm{S} / \mathrm{N}$ ratio on the fine root $\mathrm{Ca}(0.322)$ and $\mathrm{C} / \mathrm{N}$ ratio $(-0.235)$ were stronger than the impacts on soil $\mathrm{pH}$ and soil phosphatase activity. The indirect effects of acid rain $\mathrm{pH}$ $(0.757)$ on the fine root decomposition rate proceeded primarily through altered soil $\mathrm{pH}$ and enzyme activities. However, the indirect effects of the acid rain $\mathrm{S} / \mathrm{N}$ ratio (0.265) on the decomposition rate occurred principally through changes in the fine root $\mathrm{C} / \mathrm{N}$ ratio, Ca content, and soil urease activity (Table 1 ).

\section{Discussion}

Recently, China has brought $\mathrm{SO}_{2}$ emissions under control toward the mitigation of acid rain contamination. However, $\mathrm{NO}_{2}$ emissions have not decreased significantly, which has led to progressive changes in the composition of acid rain, from sulfuric acid rain (SAR) to nitric acid rain (NAR) (Liu et al. 2020). This study represents an attempt to elucidate how different acid rain treatments impact fine root decomposition patterns through changing abiotic and biotic factors.

\section{Effects of acid rain on fine root decomposition through changing abiotic factors}

The decomposition of fine roots is an important resource for the soil $\mathrm{C}$ pool, which is primarily influenced by climate, soil environment, and its own quality (Allison et al. 2018; Li et al. 2020). In this study, we found that the fine root decomposition rate of $C$. lanceolata decreased under 


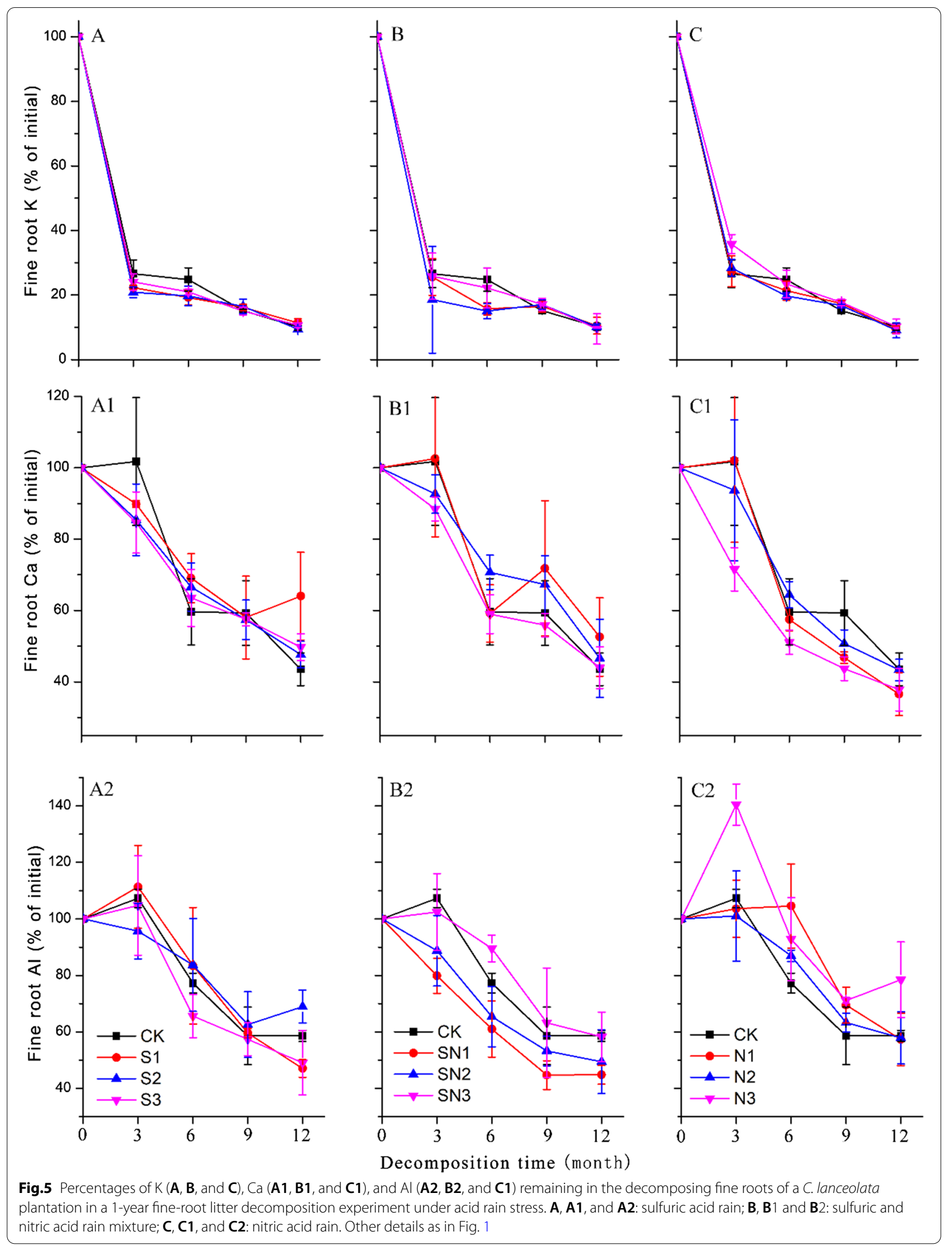




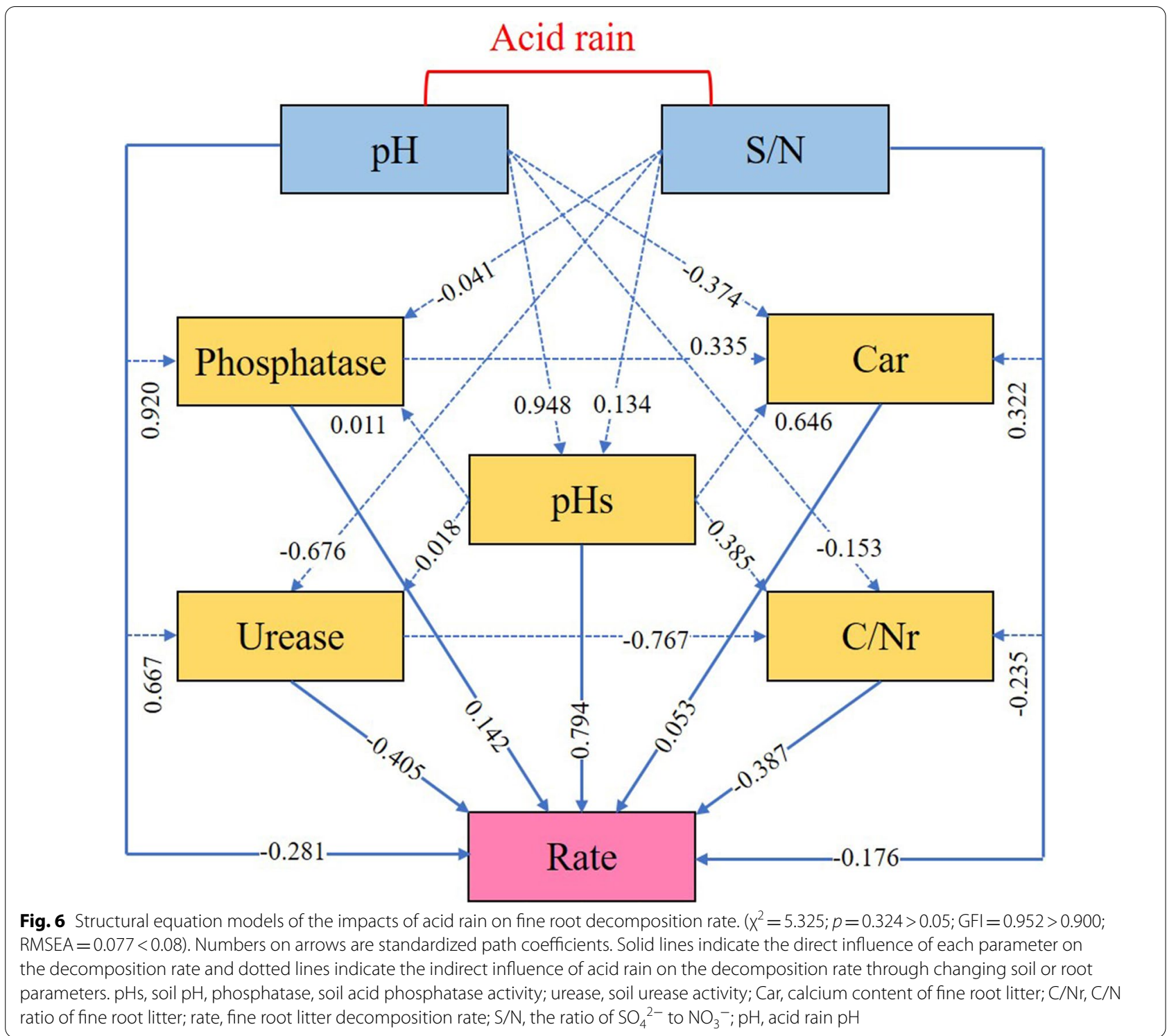

Table 1 Direct, indirect, and total effects of acid rain, soil traits, and litter quality on fine root litter decomposition rate based on structural equation models

\begin{tabular}{|c|c|c|c|c|c|c|c|}
\hline Factors & $\mathrm{pH}$ & $\mathrm{S} / \mathrm{N}$ & pHs & Phosphatase & Urease & $\mathrm{C} / \mathrm{Nr}$ & Car \\
\hline Total & 0.476 & 0.090 & 0.679 & 0.160 & -0.108 & -0.387 & 0.053 \\
\hline Direct & -0.281 & -0.176 & 0.794 & 0.142 & -0.405 & -0.387 & 0.053 \\
\hline Indirect & 0.757 & 0.265 & -0.115 & 0.018 & 0.297 & / & / \\
\hline
\end{tabular}

$\mathrm{S} / \mathrm{N}$ the ratio of $\mathrm{SO}_{4}{ }^{2-}$ to $\mathrm{NO}_{3}{ }^{-} ; \mathrm{pH}$ acid rain $\mathrm{pH}$. $\mathrm{pHs}$ soil $\mathrm{pH}$, Phosphatase soil acid phosphatase activity, Urease soil urease activity; $\mathrm{C} / \mathrm{Nr} \mathrm{C} / \mathrm{N}$ ratio of fine-root litter, $\mathrm{Car}$ calcium content of fine root litter

lower acid rain $\mathrm{pH}$, but not significantly (Fig. 3D), which was consistent with our previous studies regarding the decomposition of Q. acutissima litter (Liu et al. 2017a). In addition, strongly acidic rain with higher $\mathrm{NO}_{3}{ }^{-}$concentrations (SN3 and N3) significantly decreased the fine root decomposition rate compared with the CK treatment (Fig. 3D), which supported our second hypothesis. Previous investigations revealed that acid rain with an increased $\mathrm{NO}_{3}{ }^{-}$content aggravated soil acidification (Liu et al. 2019, 2017a) and affected the decomposition of 
fine roots, which was not significant in the present study (Additional file 1: Fig. S4). This may have been due to the experimental period (1 year) of this study being too short. In addition, based on SEM analysis, we found that the overall inhibitory effect of acid rain $\mathrm{pH}$ on fine root decomposition was stronger than that of acid rain $\mathrm{NO}_{3}{ }^{-}$, which was consistent with our previous research results on fine root growth (Liu et al. 2018). This may have been due to acid rain $\mathrm{pH}(0.948)$ having a stronger effect on soil acidification than the $\mathrm{NO}_{3}{ }^{-}$content (0.134) (Fig. 6).

In contrast to our findings, several other studies found that acid rain could neutrally or positively impact the decomposition of litter in diverse ecosystems ( $\mathrm{Lv}$ et al. 2014; Wei et al. 2020). This may have been due to the differences in plant species, acid rain intensity, and simulation time (Wei et al. 2020). Furthermore, the $\mathrm{S}$ and $\mathrm{N}$ of acid rain can provide nutrients for decomposers, thus stimulating the decomposition of litter, particularly during the initial stages of acid rain simulation (Liu et al. 2017a).

As nutrients from fine root litter are released into the soil, their basic properties are altered, which are critical driving factors for litter decomposition (Wang et al. 2019). Diverse elemental constituents showed variable dynamics under particular compositions of acid rain. A previous study found that acid rain could alter the litter decomposition rate by indirectly affecting litter quality (Wei et al. 2020). However, in this study, we found that the acid rain $\mathrm{pH}$ had no significant effects on the TC and TN contents of fine root litter over the four decomposition periods (Additional file 1: Fig. S4), which was consistent with previous studies (Wei et al. 2020). Conversely, we found that the $\mathrm{S} / \mathrm{N}$ ratio of acid rain significantly influenced the remaining TN (\% of initial, Additional file 1: Table S3) and TN contents over 3 and 9 months (Additional file 1: Table S4). This may have been because the acid rain $\mathrm{S} / \mathrm{N}$ significantly influences the activities of soil urease (Additional file 1: Table S2), which impacts the $\mathrm{N}$ cycles of ecosystems (Yang et al. 2017).

Phosphorus (P) is a critical element that affects the growth and reproduction of microorganisms. The release of $\mathrm{P}$ from litter promotes the growth of microorganisms, thereby facilitating the decomposition of litter (Pourhassan et al. 2016). In our study, the TP (\% of initial) of $C$. lanceolata fine root litter under the CK treatment increased over 6 months (Fig. 4). This might explain why the P limitation in gymnosperm litter was observed only at the onset of the growing season (Jean et al. 2013), as the $P$ was not yet being effectively mobilized through the decomposition of litter (Pourhassan et al. 2016).

Furthermore, nitric acid rain shortened the duration of $\mathrm{P}$ enrichment (3 months, Fig. $4 \mathrm{C} 2$ ), which indirectly implied that $\mathrm{P}$ limitation might appear earlier under nitric acid stress (Jean et al. 2013). Prior studies revealed that high-quality litter with higher $\mathrm{N}$ and $\mathrm{P}$ concentrations and lower $\mathrm{C} / \mathrm{N}$ ratios decomposed more quickly (Patoine et al. 2017). This was consistent with our results, as there was a positive correlation between the TN and TP contents and the decomposition rate, whereas a negative correlation was found between the $\mathrm{C} / \mathrm{N}$ and decomposition rates (Additional file 1: Fig. S4).

For this study, we found that the litter content of $\mathrm{Ca}$ $\left(1.95 \pm 0.27 \mathrm{~g} \mathrm{~kg}^{-1}\right)$ and $\mathrm{Al}\left(5.13 \pm 0.43 \mathrm{~g} \mathrm{~kg}^{-1}\right)$ (for the CK treatment during the early decomposition stage) were higher than the initial contents $\mathrm{Ca}\left(1.66 \pm 0.19 \mathrm{~g} \mathrm{~kg}^{-1}\right)$ and $\mathrm{Al}\left(4.12 \pm 0.29 \mathrm{~g} \mathrm{~kg}^{-1}\right)$ (Additional file 1: Table S5), which was consistent with multiple earlier studies (Cao et al. 2018; Yue et al. 2016). This might have been attributed to potential mechanisms such as the formation of chelates and complexes at active sites on the organic molecules of decomposing detritus (Yue et al. 2016).

However, there was a significantly positive correlation between the Ca content and the acid rain $\mathrm{pH}$ (Additional file 1: Fig. S4). This indicated that stronger acid rain accelerated the release of $\mathrm{Ca}$ from fine root litter. Moreover, McCay et al. (2013) demonstrated that invertebrate soil dwelling organisms such as earthworms prefer calciumrich substances for food, which promotes litter decomposition. Thus, we speculated that acid rain reduced the $\mathrm{Ca}$ content of fine root litter, which may have decreased the activity of earthworms that indirectly enhanced the inhibition of acid rain on the decomposition of fine roots.

\section{Effects of acid rain on fine root decomposition through changing biotic factors}

Soil enzymes play critical roles in the cycling of nutrients in forest ecosystems, such as urease and phosphatase, which participate in the nitrogen and phosphorus cycles (Gu et al. 2019; Liu et al. 2020). In our study, we observed that the activities of soil enzymes (e.g., urease, acid phosphatase, sucrose, and catalase) significantly decreased under lower acid rain pH (Fig. 2), which was consistent with the results of prior studies (Lv et al. 2014; Chen et al. 2019). This was because acid rain $\mathrm{pH}$ had the capacity to directly damage soil enzyme systems (Wei et al. 2020), which further influenced the decomposition of litter.

We also found that the soil $\mathrm{pH}$ significantly affected the patterns of soil enzyme activities (Additional file 1: Fig. S4), which indirectly influenced the decomposition of fine root litter, as indicated by earlier studies (Liu et al. 2019; Lv et al. 2014). Furthermore, the inhibition of litter decomposition can result in the reduction of substrates that are directly utilized by microorganisms, which translates to lower soil enzyme activities (Tang et al. 2019). Thus, we found that soil enzyme activities were positively 
correlated with the decomposition rate of fine roots, which was consistent with our rationale above.

Previous studies revealed that the addition of $\mathrm{N}$ had positive, neutral, or negative effects on the activities of soil enzymes (Jing et al. 2017; Liu and Zhang, 2019). In this study, we found that the activities of soil urease intensified with the higher $\mathrm{N}$ content of acid rain (Fig. 4A), which was consistent with the reports of Guan et al. (2019). However, the soil urease activities under the acid rain treatments were still lower than that of the CK. This was primarily due to the inhibitory effects of acid rain $\mathrm{pH}$ being stronger than promotional effects of the added N. Furthermore, Guan et al. (2019) found that the addition of $\mathrm{N}$ stimulated microbial activities and increased $\mathrm{P}$ concentrations, which enhanced the presence of $\mathrm{P}$ acquiring enzymes. In this study, the activities of acid phosphatase increased only under the weaker acid rain treatments in contrast to the CK treatment (Fig. 4B). However, more potent acid rain $(\mathrm{pH} 2.5)$ with higher $\mathrm{N}$ inputs significantly decreased phosphatase activity. This verified once again that the inhibitory effects of acid rain $\mathrm{pH}$ on soil enzyme activities were stronger than the promotional effects of $\mathrm{N}$ inputs.

\section{Conclusion}

Following a four-season mesocosm experiment, acid rain treatments led to modifications in elemental dynamics and soil properties during the decomposition of fine root litter in the Yangtze River Delta region of China. Both acid rain $\mathrm{pH}$ value and $\mathrm{NO}_{3}{ }^{-}$content aggravated soil acidification, which inhibited the decomposition of fine roots. The effects of soil enzyme activities on the decomposition of fine root litter were stronger than the elemental dynamics under acid rain stress. The inhibitory effects of acid rain $\mathrm{pH}$, which altered the soil $\mathrm{pH}$ and enzyme activities on the decomposition of fine root litter, were greater than the impacts of the acid rain $\mathrm{S} / \mathrm{N}$ ratio through changes in the fine root $\mathrm{C} / \mathrm{N}$ ratio, $\mathrm{Ca}$ content, and soil urease activities. In summary, we found that acid rain altered the decomposition of fine roots, primarily by modifying the activities of soil enzymes through acid rain $\mathrm{pH}$; however, changes in the $\mathrm{S} / \mathrm{N}$ ratio exacerbated the negative effects of acid rain $\mathrm{pH}$.

\section{Supplementary Information}

The online version contains supplementary material available at https://doi. org/10.1186/s13717-021-00334-0.

Additional file 1: Table S1. Initial chemistry of C. lanceolata fine roots. Table S2. The $p$ values of variance analysis under the impacts of simulated acid rain on soil enzyme activities. Table S3. The $p$ values of variance analysis under the impacts of acid rain on remaining mass and element contents of fine root litter. Table S4. Contents of biomass, TC, TN, and $\mathrm{C} / \mathrm{Nr}$ of decomposing C. lanceolata fine-roots under the stress of acid rain. Table S5. Contents of TP, K, Ca and Al of decomposing C. lanceolata fine-roots under the stress of acid rain. Fig. S1. Distribution map of annual mean precipitation $\mathrm{pH}$ value of China in 2020 according to the Environment Bulletin of China in 2020. Fig. S2. Schematic diagram of experimental layout. Fig. $\mathbf{S 3}$. Effects of simulated acid rain treatments on soil nutrients over four decomposition periods. Fig. S4. The Pearson relationships between fine root decomposition and soil properties under the stress of acid rain.

\section{Acknowledgements}

We would like to thank Frank Boehm, from Lakehead University, for the language editing of this manuscript.

\section{Authors' contributions}

$\mathrm{JZ}$ and $\mathrm{XL}$ conceived and designed the study. MM and $\mathrm{YZ}$ revised and perfected the design of the experiments. XL, CL, SM, QL and QR performed the experiments. Xin Liu wrote the paper. YZ and JZ reviewed and edited the manuscript. All authors read and approved the manuscript.

\section{Funding}

This research was funded by the Jiangsu Province Science Foundation for Youths (BK20200785), the China Postdoctoral Science Foundation (2018M642260), the Jiangsu Agriculture Science and Technology Innovation Fund (CX(17)1004), and the Priority Academic Program Development of Jiangsu Higher Education Institutions (PAPD).

\section{Availability of data and materials}

The data sets used and/or analyzed during the current study are available from the corresponding author on reasonable request.

\section{Declarations}

Ethics approval and consent to participate

Not applicable.

\section{Consent for publication}

Not applicable.

\section{Competing interests}

The authors declare that they have no competing interests.

\section{Author details}

${ }^{1}$ Co-Innovation Center for Sustainable Forestry in Southern China, Jiangsu Province Key Laboratory of Soil and Water Conservation and Ecological Restoration, Nanjing Forestry University, 159 Longpan Road, Nanjing 210037, Jiangsu, China. ${ }^{2}$ Zhejiang Provincial Public Forest and State-Owned Forest Farm Management Station, 226 Kaixuan Road, Hangzhou, Zhejiang, China. ${ }^{3}$ Jiangxi Academy of Forestry, 1629 Fenglin Road, Nanchang 330032, Jiangxi, China. ${ }^{4}$ Co-Innovation Center for Sustainable Forestry in Southern China, Nanjing Forestry University, 159 Longpan Road, Nanjing 210037, Jiangsu, China.

Received: 28 April 2021 Accepted: 24 September 2021

Published online: 12 October 2021

\section{References}

Allison SD, Lu Y, Weihe C, Goulden ML, Martiny AC, Martiny JBH, Treseder KK (2018) Decomposition responses to climate depend on microbial community composition. Proc Natl Acad Sci 115(47):1 1994-11999

Bradford MA, Berg B, Maynard DS, Wieder WR, Wood SA (2016) Understanding the dominant controls on litter decomposition. J Ecol 104(1):229-238

Brandt LA, King JY, Hobbie SE, Milchunas DG, Sinsabaugh RL (2010) The role of photodegradation in surface litter decomposition across a grassland ecosystem precipitation gradient. Ecosystems 13:1-17

Cao C, Liu S, Ma Z, Lin Y, Su Q, Chen H, Wang J (2018) Dynamics of multiple elements in fast decomposing vegetable residues. Sci Total Environ 616-617:614-621 
Chao L, Liu Y, Freschet GT, Zhang W, Yu X, Zheng W, Guan X, Yang Q, Chen L, Dijkstra FA, Wang S (2019) Litter carbon and nutrient chemistry control the magnitude of soil priming effect. Funct Ecol 33(5):876-888

Chen S, Sun L, Zhang X, Shen X, Liu Y, Ren J (2019) Contrasting effects of longterm acid rain simulation on temperature sensitivity of soil respiration and enzymatic activities in a subtropical forest. J Soils Sediments 20(1):412-424

Couteaux MM, Bottner P, Berg B (1995) Litter decomposition, climate and liter quality. Trends Ecol Evol 10(2):63-66

DeForest UL (2019) Chronic phosphorus enrichment and elevated pH suppresses Quercus spp. leaf litter decomposition in a temperate forest. Soil Biol Biochem 135:206-212

Fang YT, Koba K, Wang XM, Wen DZ, Li J, Takebayashi Y, Liu XY, Yoh M (201 1) Anthropogenic imprints on nitrogen and oxygen isotopic composition of precipitation nitrate in a nitrogen-polluted city in southern China. Atmos Chem Phys 11(3):1313-1325

Gu C, Zhang S, Han P, Hu X, Xie L, Li Y, Brooks M, Liao X, Qin L (2019) Soil enzyme activity in soils subjected to flooding and the effect on nitrogen and phosphorus uptake by oilseed rape. Front Plant Sci 10:368

Guan B, Xie B, Yang S, Hou A, Chen M, Han G (2019) Effects of five years' nitrogen deposition on soil properties and plant growth in a salinized reed wetland of the Yellow River Delta. Ecol Eng 136:160-166

Huang J, Wang H, Zhong Y, Huang J, Fu X, Wang L, Teng W (2019) Growth and physiological response of an endangered tree, Horsfieldia hainanensis Merr., to simulated sulfuric and nitric acid rain in southern China. Plant Physiol Biochem 144:118-126

Jean ME, Phalyvong K, Forest-Drolet J, Bellenger JP (2013) Molybdenum and phosphorous limitation of asymbiotic nitrogen fixation in forests of Eastern Canada: influence of vegetative cover and seasonal variability. Soil Biol Biochem 67:140-146

Jing X, Chen X, Tang M, Ding Z, Jiang L, Li P, Ma S, Tian D, Xu L, Zhu J, Ji C, Shen H, Zheng C, Fang J, Zhu B (2017) Nitrogen deposition has minor effect on soil extracellular enzyme activities in six Chinese forests. Sci Total Environ 607-608:806-815

Li Y, Yu X, Cheng H, Lin W, Tang J, Wang S (2010) Chemical characteristics of precipitation at three Chinese regional background stations from 2006 to 2007. Atmos Res 96(1):173-183

LiY, Chen Z, He JZ, Wang Q, Shen C, Ge Y (2019) Ectomycorrhizal fungi inoculation alleviates simulated acid rain effects on soil ammonia oxidizers and denitrifiers in Masson pine forest. Environ Microbiol 21(1):299-313

Li Q, Zhang M, Geng Q, Jin C, Zhu J, Ruan H, Xu X (2020) The roles of initial litter traits in regulating litter decomposition: a "common plot" experiment in a subtropical evergreen broadleaf forest. Plant Soil 452(1-2):207-216

Liang G, Hui D, Wu X, Wu J, Liu J, Zhou G, Zhang D (2016) Effects of simulated acid rain on soil respiration and its components in a subtropical mixed conifer and broadleaf forest in southern China. Environ Sci-Proc Imp 18:246-255

Ling DJ, Huang QC, Ouyang Y (2010) Impacts of simulated acid rain on soil enzyme activities in a latosol. Ecotoxicol Environ Saf 73:1914-1918

Liu X, Zhang S (2019) Nitrogen addition shapes soil enzyme activity patterns by changing $\mathrm{pH}$ rather than the composition of the plant and microbial communities in an alpine meadow soil. Plant Soil 440(1):11-24

Liu X, Zhang B, Zhao W, Wang L, Xie D, Huo W, Wu Y, Zhang J (2017a) Comparative effects of sulfuric and nitric acid rain on litter decomposition and soil microbial community in subtropical plantation of Yangtze River Delta region. Sci Total Environ 601:669-678

Liu G, Sun J, Tian K, Xiao D, Yuan X (2017b) Long-term responses of leaf litter decomposition to temperature, litter quality and litter mixing in plateau wetlands. Freshw Biol 62(1):178-190

Liu X, Zhao W, Meng M, Fu Z, Xu L, Zha Y, Yue J, Zhang S, Zhang J (2018) Comparative effects of simulated acid rain of different ratios of $\mathrm{SO}_{4}{ }^{2-}$ to $\mathrm{NO}_{3}{ }^{-}$on fine root in subtropical plantation of China. Sci Total Environ 618:336-346

Liu M, Huang X, Song Y, Tang J, Cao J, Zhang X, Zhang Q, Wang S, Xu T, Kang L, Cai $X$, Zhang H, Yang F, Wang H, Yu JZ, Lau AKH, He L, Huang X, Duan L, Ding A Xue L, Gao J, Liu B, Zhu T (2019) Ammonia emission control in China would mitigate haze pollution and nitrogen deposition, but worsen acid rain. Proc Natl Acad Sci 116(16):7760-7765

Liu X, Li C, Meng M, Zhai L, Zhang B, Jia Z, Gu Z, Liu Q, Zhang Y, Zhang J (2020) Comparative effects of the recovery from sulfuric and nitric acid rain on the soil enzyme activities and metabolic functions of soil microbial communities. Sci Total Environ 714:136788

Lv Y, Wang C, Jia Y, Wang W, Ma X, Du J, Tian X (2014) Effects of sulfuric, nitric, and mixed acid rain on litter decomposition, soil microbial biomass, and enzyme activities in subtropical forests of China. Appl Soil Ecol 79:1-9

McCay T, Cardelus C, Neatrour M (2013) Rate of litter decay and litter macroinvertebrates in limed and unlimed forests of the Adirondack Mountains, USA. For Ecol Manage 304:254-260

Patoine G, Thakur MP, Friese J, Nock C, Hönig L, Haase J, Scherer-Lorenzen M, Eisenhauer N (2017) Plant litter functional diversity effects on litter mass loss depend on the macro-detritivore community. Pedobiologia 65:29-42

Penner JF, Frank DA (2019) Litter decomposition in Yellowstone grasslands: the roles of large herbivores, litter quality, and climate. Ecosystems 22(4):929-937

Pourhassan N, Bruno S, Jewell MD, Shipley B, Roy S, Bellenger J-P (2016) Phosphorus and micronutrient dynamics during gymnosperm and angiosperm litters decomposition in temperate cold forest from Eastern Canada. Geoderma 273:25-31

See CR, Luke McCormack M, Hobbie SE, Flores-Moreno H, Silver WL, Kennedy PG (2019) Global patterns in fine root decomposition: climate, chemistry, mycorrhizal association and woodiness. Ecol Lett 22(6):946-953

Song X, Li Q, Gu H (2017) Effect of nitrogen deposition and management practices on fine root decomposition in Moso bamboo plantations. Plant Soil 410:207-215

Tang L, Lin Y, He X, Han G (2019) Acid rain decelerates the decomposition of Cunninghamia lanceolata needle and Cinnamomum camphora leaf litters in a karst region in China. Ecol Res 34(1):193-200

Tresch S, Frey D, Le Bayon R, Zanetta A, Rasche F, Fliessbach A, Moretti M (2019) Litter decomposition driven by soil fauna, plant diversity and soil management in urban gardens. Sci Total Environ 658:1614-1629

Wang C, Guo P, Han G, Feng X, Zhang P, Tian X (2010) Effect of simulated acid rain on the litter decomposition of Quercus acutissima and Pinus massoniana in forest soil microcosms and the relationship with soil enzyme activities. Sci Total Environ 408(13):2706-2713

Wang Y, Yu W, Pan Y, Wu D (2012) Acid neutralization of precipitation in Northern China. J Air Waste Manag Assoc 62(2):204-211

Wang Y, Zheng J, Boyd SE, Xu Z, Zhou Q (2019) Effects of litter quality and quantity on chemical changes during eucalyptus litter decomposition in subtropical Australia. Plant Soil 442(1):65-78

Wei H, Ma R, Zhang J, Saleem M, Liu Z, Shan X, Yang J, Xiang H (2020) Crop-litter type determines the structure and function of litter-decomposing microbial communities under acid rain conditions. Sci Total Environ 713:136600

Xia M, Talhelm AF, Pregitzer KS (2018) Long-term simulated atmospheric nitrogen deposition alters leaf and fine root decomposition. Ecosystems 21(1):1-14

Yang Y, Dong M, Cao Y, Wang J, Tang M, Ban Y (2017) Comparisons of soil properties, enzyme activities and microbial communities in heavy metal contaminated bulk and rhizosphere soils of Robinia pseudoacacia L. in the Northern Foot of Qinling Mountain. Forests 8(11):430

Yu Q, Duan L (2020) Contribution of atmospheric reactive nitrogen to acid deposition in China. In: Liu X, Du E (eds) Atmospheric Reactive Nitrogen in China. Springer, Singapore, pp 155-181

Yue K, Yang W, Peng Y, Zhang C, Huang C, Xu Z, Tan B, Wu F (2016) Dynamics of multiple metallic elements during foliar litter decomposition in an alpine forest river. Ann For Sci 73(2):547-557

\section{Publisher's Note}

Springer Nature remains neutral with regard to jurisdictional claims in published maps and institutional affiliations. 